\title{
Bean dwarf mosaic virus BV1 Protein Is a Determinant of the Hypersensitive Response and Avirulence in Phaseolus vulgaris
}

\author{
E. R. Garrido-Ramirez, ${ }^{1}$ M. R. Sudarshana, ${ }^{1}$ W. J. Lucas, ${ }^{2}$ and R. L. Gilbertson ${ }^{1}$ \\ ${ }^{1}$ Department of Plant Pathology, University of California, Davis 95616, U.S.A.; ${ }^{2}$ Section of Plant Biology, \\ Division of Biological Sciences, University of California, Davis 95616, U.S.A. \\ Accepted 3 July 2000.
}

\begin{abstract}
The capacities of the begomoviruses Bean dwarf mosaic virus (BDMV) and Bean golden yellow mosaic virus (BGYMV) to differentially infect certain common bean (Phaseolus vulgaris) cultivars were used to identify viral determinants of the hypersensitive response (HR) and avirulence (avr) in BDMV. A series of hybrid DNA-B components, containing BDMV and BGYMV sequences, was constructed and coinoculated with BDMV DNA-A (BDMV-A) or BDMVA-green florescent protein into seedlings of cv. Topcrop (susceptible to BDMV and BGYMV) and the BDMV-resistant cvs. Othello and Black Turtle Soup T-39 (BTS). The BDMV avr determinant, in bean hypocotyl tissue, was mapped to the BDMV BV1 open reading frame and, most likely, to the BV1 protein. The BV1 also was identified as the determinant of the HR in Othello. However, the HR was not required for resistance in Othello nor was it associated with BDMV resistance in BTS. BDMV BV1, a nuclear shuttle protein that mediates viral DNA export from the nucleus, represents a new class of viral avr determinant. These results are discussed in terms of the relationship between the HR and resistance.
\end{abstract}

Plants have evolved an array of defense mechanisms to prevent or limit infection by viruses and other pathogens. In some situations, barriers appear to be formed prior to pathogen attack, whereas others require induction by the pathogen or the presence of pathogen-generated elicitors (Agrios 1997). One inducible mechanism that is associated with specific recognition and resistance to infection by a range of plant pathogens is the hypersensitive response (HR) (Dangl et al. 1996; Goodman and Novacky 1994; Morel and Dangl 1997). The HR is usually a highly pathogen-specific reaction involving rapid programmed cell death at the site of infection (Gilchrist 1998), as well as the activation of a cascade of signal transduction events leading to confinement of the pathogen to a localized area. The HR is considered to involve a gene-forgene interaction (Flor 1971), in which a pathogen avirulence (avr) factor interacts with a host-encoded resistance (R) pro-

Corresponding author: R. L. Gilbertson; Telephone: +1-530-752-3163; Fax: +1-530-752-5674; E-mail: rlgilbertson@ucdavis.edu

Current address of E. R. Garrido-Ramirez: INIFAP-Campo Experimental Centro de Chiapas, Apdo. Postal \#1, Ocozocoautla, Chis, 29140 Mexico. tein to activate a defense response (Gabriel and Rolfe 1990; Keen 1990; Lamb et al. 1989; Staskawicz et al. 1995). However, examples exist in which the HR and resistance have been uncoupled (Kim and Palukaitis 1997; Richael and Gilchrist 1999); therefore, the explicit role of the HR in the defense response remains to be elucidated.

With respect to RNA plant viruses, the best known examples involving the HR relate to infection by the tobamoviruses (Culver 1996; Goodman and Novacky 1994). Here, the viral determinant of HR or resistance (i.e., avr determinant) depends upon the specific host resistance gene and has been mapped to viral genes involved in each of the major steps of the tobamovirus life cycle. For Tobacco mosaic virus (TMV), the gene-for-gene interaction involves the coat protein (CP)- $\mathrm{N}^{\prime}$ gene (Culver and Dawson 1989; Knorr and Dawson 1988; Saito et al. 1987), the replicase-N gene (Padgett and Beachy 1993), and the movement protein (MP)-Tm-2 (Meshi et al. 1989) and $-T m-2^{2}$ genes (Weber et al. 1993). In the case of Pepper mild mottle virus, the CP interacts with the L2 or L3R genes in Capsicum spp. (Berzal-Herranz et al. 1994).

Avirulence determinants have also been identified for other plant virus groups (Culver 1996). For example, in potato, the $\mathrm{CP}$ of Potato virus $X$ (PVX) is an avr determinant for the $N x$ and $R x$ genes (Bendahmane et al. 1995; Kavanaugh et al. 1992), whereas the PVX 25-kDa MP is the determinant for the $\mathrm{Nb}$ gene (Malcuit et al. 1999). Additional examples include the p22 MP of Tomato bushy stunt virus in Nicotiana edwardsonii (Chu et al. 1999; Scholthof et al. 1995), the 2a polymerase gene of Cucumber mosaic virus (CMV) in cowpea (Kim and Palukaitis 1997), and the gene VI product of the double-stranded (ds) DNA virus, Cauliflower mosaic virus (Kiraly et al. 1999; Schoelz et al. 1986).

Members of the family Geminiviridae are small, singlestranded (ss) DNA plant viruses that replicate in the nucleus (Timmermans et al. 1994). The bipartite members of the genus Begomovirus have their genome divided between two approximately 2.6-kb DNA components, referred to as DNA-A and DNA-B. DNA-A encodes factors involved in viral DNA replication, gene expression, and encapsidation. The two genes encoded on DNA-B, $B V 1$ and $B C 1$, are required for systemic infection (Brough et al. 1988; Etessami et al. 1988), and it has been further established that both the BV1 and BC1 proteins are required for cell-to-cell movement (Jeffrey et al. 1996; Sudarshana et al. 1998). The BV1 protein binds viral 
DNA and mediates its export out of the nucleus into the cytoplasm, whereas the $\mathrm{BC} 1$ protein also binds DNA and potentiates the cell-to-cell movement of viral DNA (Noueiry et al. 1994; Pascal et al. 1994; Rojas et al. 1998). BV1 is also a host range determinant (Ingham and Lazarowitz 1993; Ingham et al. 1995), whereas BC1 is a symptom determinant (Hou and Gilbertson, 1996; Hou et al. 2000; Ingham and Lazarowitz 1993; Ingham et al. 1995; Pascal et al. 1993; von Arnim and Stanley 1992a).

Bean dwarf mosaic virus (BDMV) is a bipartite begomovirus (Gilbertson et al. 1991a; Hidayat et al. 1993; Morales et al. 1990) that induces epinasty, dwarfing, and mosaic symptoms in common bean (Phaseolus vulgaris L.). However, BDMV does not infect a number of bean cultivars, including the Pinto bean cvs. Othello and UI 114 and cv. Black Turtle Soup T-39 (BTS) (Hidayat 1991; Morales et al. 1990; Wang et al. 1999). Recently, the BDMV DNA-A component (BDMV-A) was tagged with the green fluorescent protein (BDMV-GFP); this construct allowed the monitoring of viral cell-to-cell and longdistance movement (Sudarshana et al. 1998; Wang et al. 1999). Studies with BDMV-GFP established that BDMV resistance in Othello and BTS involved a block in long-distance transport and, in Othello, an HR was associated with resistance. The determinant of the HR in Othello was mapped to the BDMV DNA-B component (BDMV-B) (Wang et al. 1999).

To more precisely identify the BDMV avr determinant or determinants involved in the HR in Othello and the resistance responses in Othello and BTS, hybrid DNA-B components were engineered to have sequences of BDMV and Bean golden yellow mosaic virus (BGYMV), which can systemically infect these cultivars (Morales and Niessen 1988; Wang et al. 1999). Infection studies carried out with these constructs established that the BDMV BV1 is an elicitor of the HR in Othello. Furthermore, these experiments revealed that the BDMV BV1 is also an avr determinant in the resistance responses in Othello and BTS and that, in BTS, this occurs in the absence of an HR.

\section{RESULTS}

\section{Infectivity of the HBDBG1 hybrid DNA-B component in Topcrop and Othello.}

The determinant or determinants of the HR in Othello was previously mapped to BDMV-B on the basis of results obtained with infectious pseudorecombinants generated between BDMV and Tomato mottle virus (ToMoV) (Wang et al. 1999). However, ToMoV was considered inappropriate for further mapping of this determinant because it is poorly infectious in Topcrop (Hou et al. 1998) and does not systemically infect Othello (Wang et al. 1999). Therefore, BGYMV, which systemically infects Othello and other BDMV-resistant cultivars (Gilbertson et al. 1991b; Hidayat 1991; Morales and Niessen 1988; Wang et al. 1999), was selected for these studies.

To further map the BDMV avr determinant, a series of hybrid DNA-B components, having BDMV and BGYMV sequences, were constructed (Fig. 1). Viral DNA was introduced into epidermal cells of hypocotyls of bean seedlings (2 to 3 days old) via particle bombardment. BDMV systemically infected Topcrop and induced the HR-associated resistance in Othello, whereas BGYMV systemically infected Topcrop and
Othello. It is important to note that, by this method of inoculation, the infectivity of BGYMV in Othello was lower than that in Topcrop (Table 1). Infection studies were next conducted with the HBDBG1 hybrid, which contains the BDMV common region (CR) and untranslated sequences (UTRs) and the BGYMV BV1 and BC1 open reading frames (ORFs) (Fig. 1). When either wild-type BDMV-B or the HBDBG1 hybrid was coinoculated with BDMVA-GFP into seedlings of Topcrop and Othello, extensive and comparable cell-to-cell movement was observed in cortical cells of hypocotyl tissues based on the detection of GFP fluorescence (compare Fig. 2A and E). However, in contrast to BDMV-B, the HBDBG1 hybrid did not elicit an HR in hypocotyl tissue of Othello when coinoculated with BDMVA-GFP or BDMV-A (Table 1; Fig. $2 \mathrm{D}$ versus $\mathrm{F}$ ). These results established that (i) BDMVA-GFP mediated the replication of the HBDBG1 hybrid DNA-B; (ii) the BGYMV BV1 and BC1 proteins, expressed from HBDBG1, mediated the cell-to-cell movement of BDMVA-GFP in a CP independent manner (the GFP gene is substituted in place of the $C P$ gene in BDMVA-GFP) (Sudarshana et al. 1998); and (iii) the BDMV HR determinant in Othello did not map to DNA-A or to the DNA-B CR or UTRs, but to the BV1 or BC1 ORFs.

The ability of HBDBG1 to mediate a systemic infection in Topcrop was next investigated. Control experiments conducted with BDMV-GFP resulted in high levels of infectivity and development of milder BDMV-like symptoms (Sudarshana et al. 1998) (Table 1). The HBDBG1 hybrid, coinoculated with BDMV-A or BDMVA-GFP, was also highly infectious in Topcrop (approximately 90\% infectivity), and both combinations induced mild BDMV-like symptoms (Table 1). Thus, in Topcrop, the BGYMV BV1 and BC1 proteins mediated $\mathrm{CP}$ independent long-distance transport of BDMV-A and BDMVA-GFP and a symptomatic systemic infection. However, in the BDMV background, the BGYMV BV1 and BC1 did not induce golden mosaic-like symptoms in Topcrop.

In Othello, wild-type BDMV-B, coinoculated with BDMVA or BDMVA-GFP, induced the HR in hypocotyl tissue (Fig. 2D) and failed to mediate long-distance transport of either component in inoculated seedlings. In contrast, BGYMV (Fig. 2B) or HBDBG1, coinoculated with BDMV-A or BDMVAGFP, did not induce the HR in hypocotyl tissue (Fig. 2F), and HBDBG1 mediated the long-distance transport of BDMV-A and BDMVA-GFP and a symptomless systemic infection in inoculated seedlings (Table 1). These results established that the BDMV avr determinant in Othello also did not map to BDMV-A or the BDMV-B CR or UTRs, but to the BV1 or BC1 ORFs. However, the HBDBG1 hybrid was far less efficient in mediating systemic infections by BDMV-A or BDMVA-GFP in Othello compared with Topcrop (Table 1), indicating that there are differences in the efficiency by which the BGYMV BV1 and $\mathrm{BC} 1$ proteins mediate long-distance movement of these components in these two cultivars.

To determine whether the BDMV HR or avr determinants are the $\mathrm{BV} 1$ or $\mathrm{BC} 1 \mathrm{ORFs}$ or proteins, three-component complementation experiments with BV1 and BC1 frameshift (fs) mutants were next performed. For these experiments, BDMV $\mathrm{BV} 1_{\mathrm{fs}}$ and $\mathrm{BC} 1_{\mathrm{fs}}$ mutants were used in combination with HBDBG1 BGYMV $B C 1_{\mathrm{fs}}$ or $\mathrm{BV} 1_{\mathrm{fs}}$ mutants, respectively, to provide heterologous functional $\mathrm{BV} 1 / \mathrm{BC} 1$ combinations. These DNA-B combinations were coinoculated into hypocotyl 
BDMV-B

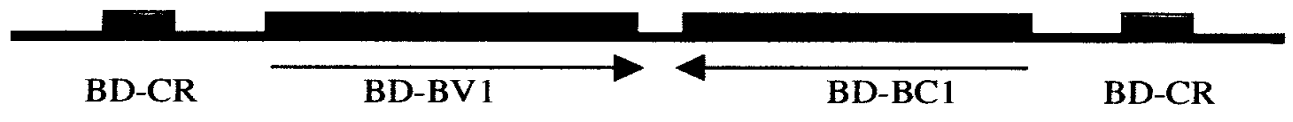

BGYMV-B

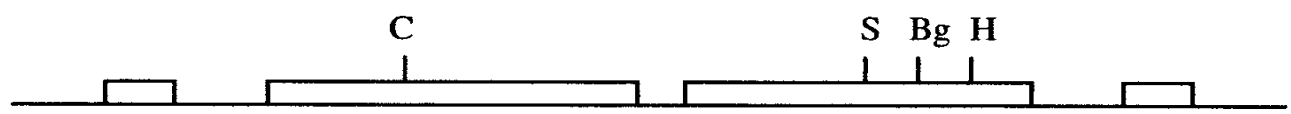

BG-CR

BG-BV1

BG-BC1

BG-CR

HBDBG1

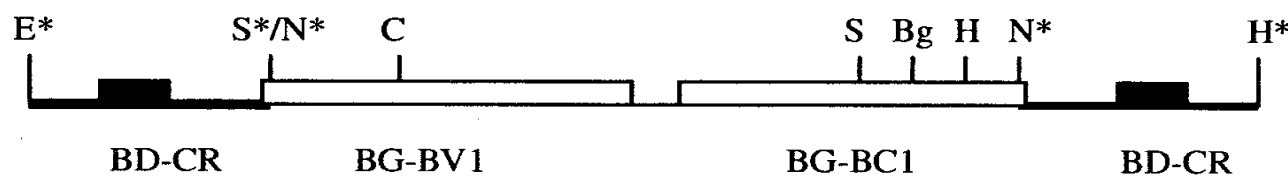

HBDBGBV $1_{\text {fs }}$

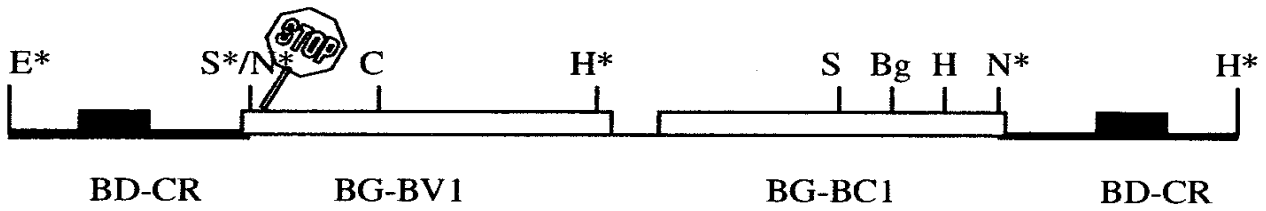

HBDBGBC $1_{\text {fs }}$

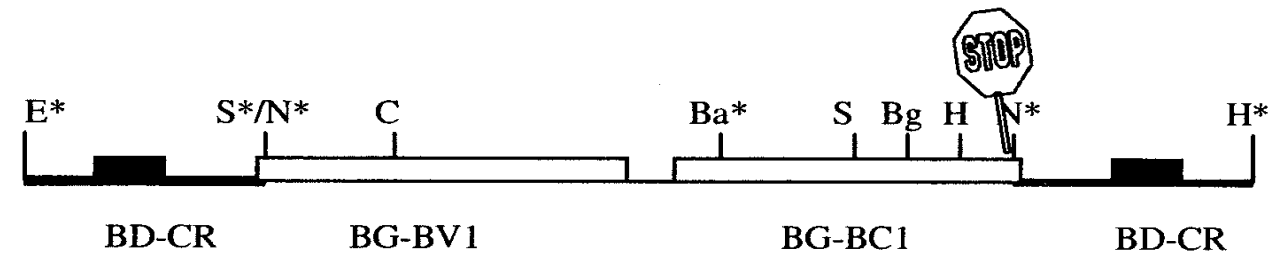

HBDBG4

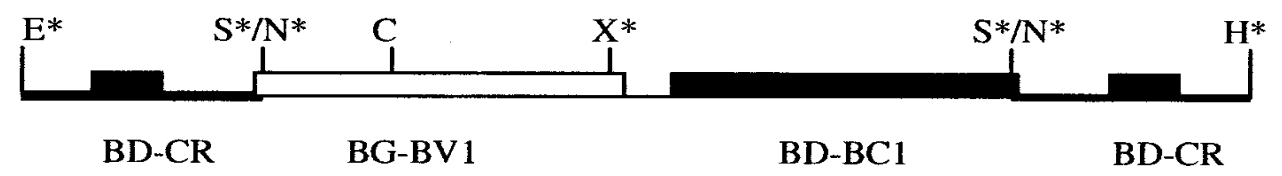

HBDBG6

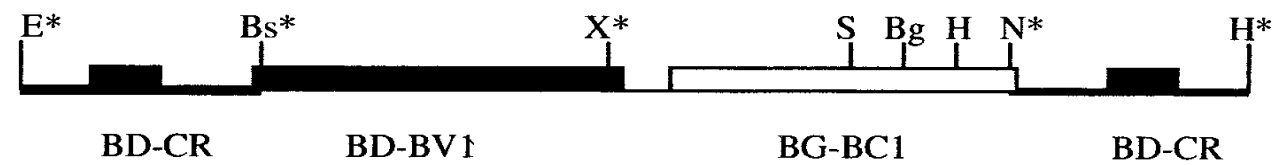

Fig. 1. Bean dwarf mosaic virus (BDMV) and Bean golden yellow mosaic virus (BGYMV) DNA-B constructs used to identify the BDMV avirulence determinant (or determinants) and hypersensitive response in Phaseolus vulgaris. Solid and open boxes represent BDMV and BGYMV open reading frames (ORFs), respectively; arrows indicate the direction of transcription of the BV1 and BC1 ORFs; thick lines represent BDMV untranslated regions (UTRs) and thin lines represent BGYMV UTRs. The stop signals indicate introduced frameshift mutations. Restriction sites are indicated as follows: Ba = $B a m \mathrm{HI}, \mathrm{Bg}=B g l \mathrm{II}, \mathrm{Bs}=B s p \mathrm{EI}, \mathrm{C}=C l a \mathrm{I}, \mathrm{E}=E c o \mathrm{RI}, \mathrm{H}=\operatorname{HindIII}, \mathrm{N}=$ Nhe $\mathrm{I}, \mathrm{S}=S a c \mathrm{I}$, and $\mathrm{X}=X b a \mathrm{I}$; asterisks indicate introduced sites. 
tissues with BDMVA-GFP. In general, the infectivity of these combinations was low, even in Topcrop (Table 2), which likely reflected the inefficient nature of these tripartite viruses. The observed high infectivity of the combination with the BDMV fs mutants (Table 2) was probably due to recombination as previously found by Noueiry (1995).

The tripartite virus having BDMVA-GFP, BGYMV BV1 $\left(\mathrm{HBDBG}-\mathrm{BC} 1_{\mathrm{fs}}\right)$, and BDMV BC1 (BD-BV1 $\left.1_{\mathrm{fs}}\right)$ moved efficiently cell to cell in hypocotyl tissues of Topcrop and Othello and, importantly, did not elicit an HR in Othello (Table 2). This virus induced a systemic infection and mild BDMV-like symptoms in $50 \%$ of inoculated Topcrop seedlings, whereas it induced a symptomless systemic infection in a small number (11\%) of Othello seedlings (Table 2). These results suggested that the BDMV BC1 ORF/protein and the BV1 ORF/RNA transcript (provided by BD-BV1 $1_{\mathrm{fs}}$ ) are not the BDMV HR/avr determinants. In contrast, a tripartite virus having BDMVAGFP, BDMV BV1 (BD-BC1 $1_{\mathrm{fs}}$ ), and BGYMV BC1 (HBDBG$B V 1_{\mathrm{fs}}$ ) was inefficient in cell-to-cell movement in Topcrop and Othello and did not elicit the HR in Othello hypocotyls (Table 2). This virus induced a symptomatic systemic infection in only $17 \%$ of inoculated Topcrop seedlings and did not systemically infect Othello seedlings. This suggested that, in these tripartite combinations, the BDMV BV1/BGYMV BC1 combination was less efficient than the BGYMV BV1/BDMV $\mathrm{BC} 1$ combination in facilitating BDMVA-GFP cell-to-cell and long-distance movement in both cultivars. The results of these experiments were consistent with the BDMV BV1 protein, rather than the ORF, being an avr determinant in Othello.

To further identify the BDMV HR/avr determinant in Othello, DNA-B hybrids having heterologous BV1-BC1 combinations provided from a single component were gener-

Table 1. Induction of the hypersensitive response (HR) and cell-to-cell or long-distance movement by Bean golden yellow mosaic virus (BGYMV), Bean dwarf mosaic virus (BDMV), and the HBDBG1 BDMV/BGYMV DNA-B hybrid in common bean (Phaseolus vulgaris) cvs. Othello and Topcrop

\begin{tabular}{|c|c|c|c|c|c|c|}
\hline \multirow[b]{2}{*}{ Virus $^{\mathrm{a}}$} & \multicolumn{3}{|c|}{ Othello } & \multicolumn{3}{|c|}{ Topcrop } \\
\hline & $\mathbf{H R}^{\mathrm{b}}$ & Cell-to-cell ${ }^{c}$ & Long-distance $^{\mathrm{d}}$ & HR & Cell-to-cell & Long-distance \\
\hline BGYMV-A + BGYMV-B & $0 / 12^{\mathrm{e}}$ & - & $4 / 12 *$ & $0 / 12$ & - & $11 / 12 * *$ \\
\hline BDMV-A + BDMV-B & $6 / 6$ & - & $0 / 6$ & $0 / 10$ & - & $9 / 10 * *$ \\
\hline BDMVA-GFP + BDMV-B & $43 / 54$ & $43 / 54$ & $0 / 12$ & $0 / 31$ & $25 / 31$ & $25 / 31 *$ \\
\hline BDMV-A + HBDBG1 & $0 / 10$ & - & $9 / 30+$ & $0 / 10$ & - & $9 / 10 *$ \\
\hline BDMVA-GFP + HBDBG1 & $0 / 70$ & $67 / 70$ & $6 / 77+$ & $0 / 35$ & $33 / 35$ & $25 / 28 *$ \\
\hline Gold & $0 / 52$ & - & $0 / 32$ & $0 / 32$ & - & $0 / 30$ \\
\hline
\end{tabular}

${ }^{\mathrm{a}}$ BDMVA-GFP = BDMV DNA-A (BDMV-A) tagged with the green fluorescent protein (GFP); HBDBG1 = DNA-B hybrid with the BDMV DNA-B (BDMV-B) common region and untranslated regions and the BGYMV BV1 and BC1 open reading frames; and Gold = gold particles used alone as a control.

${ }^{\mathrm{b}} \mathrm{HR}$ was detected by examination of transverse hypocotyl sections, 4 to 5 days postinoculation (dpi), with fluorescence or light microscopy.

${ }^{c}$ Cell-to-cell movement was assessed based on detection of GFP fluorescence, 4 to $5 \mathrm{dpi}$, in transverse hypocotyl sections with fluorescence microscopy; - indicates that cell-to-cell movement could not be observed when wild-type BDMV-A or BGYMV-A was inoculated.

${ }^{\mathrm{d}}$ Long-distance movement (systemic infection) was determined based on symptom development (indicated by asterisks) or polymerase chain reaction (PCR) analysis of total genomic DNA extracted from the third trifoliolate leaf, collected at 14 dpi. Relative degree of symptom development is indicated as follows: $*=$ mild symptoms, $* *=$ moderate symptoms, $* * *=$ severe symptoms, and $+=$ no symptoms, but DNA-A and DNA-B were detected by PCR with degenerate primers (Rojas et al. 1993).

e Number of plants in which either HR, GFP (cell-to-cell movement), or symptoms/viral DNA (long-distance movement) were detected/total number of seedlings inoculated. Numbers represent totals for three independent experiments.

Table 2. Induction of the hypersensitive response (HR) and cell-to-cell or long-distance movement by green fluorescent protein (GFP)-tagged Bean dwarf mosaic virus (BDMV), and tripartite combinations of BDMVA-GFP and BDMV or Bean golden yellow mosaic virus (BGYMV) DNA-B frameshift (fs) mutants in common bean (Phaseolus vulgaris) cvs. Othello and Topcrop

\begin{tabular}{|c|c|c|c|c|c|c|}
\hline Component/open reading frame $(\mathrm{ORF})$ combination ${ }^{\mathrm{a}}$ & & Othello & & & Topcrop & \\
\hline B & $\mathbf{H R}^{\mathbf{b}}$ & Cell-to-cell ${ }^{\mathrm{c}}$ & Long-distance $^{d}$ & HR & Cell-to-cell & Long-distance \\
\hline BDMVA-GFP + BDMV-B & $24 / 26^{\mathrm{e}}$ & $24 / 26$ & $0 / 15$ & $0 / 9$ & 9/9 & $5 / 7 * *$ \\
\hline BDMVA-GFP + HBDBG1 & $0 / 18$ & $17 / 18$ & $2 / 13+$ & $0 / 15$ & $14 / 15$ & $5 / 11 *$ \\
\hline BDMVA-GFP $+\mathrm{HBDBGBV}_{\mathrm{fs}}+\mathrm{BD}-\mathrm{BC} 1_{\mathrm{fs}}$ & $0 / 35$ & $2 / 35$ & $0 / 35$ & $0 / 6$ & $2 / 6$ & $1 / 6 *$ \\
\hline BDMVA-GFP + HBDBGBC1 $1_{\mathrm{fs}}+\mathrm{BD}-\mathrm{BV} 1_{\mathrm{fs}}$ & $0 / 34$ & $30 / 34$ & $2 / 19+$ & $0 / 9$ & $6 / 9$ & $4 / 8 *$ \\
\hline $\mathrm{BDMVA-GFP}+\mathrm{HBDBGBV} 1_{\mathrm{fs}}+\mathrm{HBDBGBC}_{\mathrm{fs}}$ & $0 / 41$ & $6 / 41$ & $0 / 24$ & $0 / 12$ & $8 / 12$ & $1 / 15 *$ \\
\hline BDMVA-GFP + BD-BV1 $1_{\mathrm{fs}}+\mathrm{BD}-\mathrm{BC} 1_{\mathrm{fs}}$ & $3 / 12$ & $3 / 12$ & $0 / 6$ & $0 / 12$ & $10 / 12$ & $9 / 12 *$ \\
\hline Gold $\quad \ldots$ & $0 / 30$ & - & $0 / 30$ & $0 / 9$ & $0 / 9$ & $0 / 9$ \\
\hline
\end{tabular}

${ }^{a}$ BDMVA-GFP = BDMV DNA-A (BDMV-A) tagged with the GFP; BDB = BDMV DNA-B; HBDBG1 = DNA-B hybrid with the BDMV DNA-B (BDMV-B) common region and untranslated regions and the BGYMV BV1 and BC1 ORFs; HBDBGBV1 $1_{\mathrm{fs}}=\mathrm{HBDBG1}$ with an fs mutation in BGYMV BV1 ORF; HBDBGBC1 $1_{\mathrm{fs}}=$ HBDBG1 with an fs mutation in the BGYMV BC1 ORF; BD-BC1 $1_{\mathrm{fs}}=\mathrm{BDMV} \mathrm{BC1} \mathrm{fs} \mathrm{mutation;} \mathrm{BD}-\mathrm{BV} 1_{\mathrm{fs}}=$ BDMV BV1 fs mutation (Noueiry et al., 1994); and Gold = gold particles used alone as a control.

${ }^{\mathrm{b}} \mathrm{HR}$ was detected by examination of transverse hypocotyl sections, 4 to 5 days postinoculation (dpi), with fluorescence and light microscopy.

${ }^{\mathrm{c}}$ Cell-to-cell movement was assessed based on detection of GFP fluorescence, 4 to $5 \mathrm{dpi}$, in transverse hypocotyl sections with fluorescence microscopy; - indicates that cell-to-cell movement could not be observed.

${ }^{\mathrm{d}}$ Long-distance movement (systemic infection) was determined based on symptom development (indicated by asterisks) or by polymerase chain reaction (PCR) analysis of total genomic DNA extracted from the third trifoliolate leaf, collected at 14 dpi. Relative degree of symptom development is indicated as follows: $*=$ mild symptoms, $* *=$ moderate symptoms, $* * *=$ severe symptoms, $+=$ no symptoms, but DNA-A and DNA-B were detected by PCR with degenerate primers (Rojas et al. 1993).

${ }^{\mathrm{e}}$ Number of plants in which either HR, GFP (cell-to-cell movement), or symptoms/viral DNA (long-distance movement) were detected/total number of seedlings inoculated. Numbers represent totals for three independent experiments. 
ated. These constructs, HBDBG4 (BGYMV BV1/BDMV BC1) and HBDBG6 (BDMV BV1/BGYMV BC1), were first individually coinoculated with BDMV-A or BDMVA-GFP into seedlings of Topcrop to determine whether the BDMV or BGYMV BV1 and BC1 proteins were functionally interchangeable in a cultivar susceptible to both viruses. In contrast to the tripartite viruses, both hybrids induced systemic symptoms in all inoculated seedlings (Table 3 ). The symptoms induced by both hybrids were BDMV-like, but slightly milder than those induced by the HBDBG1 hybrid. These experiments established that, in Topcrop, the BDMV or BGYMV $\mathrm{BV} 1$ and $\mathrm{BC} 1$ proteins were functionally interchangeable and, in either combination, could mediate the cell-to-cell movement and long-distance transport of BDMV-A and BDMVAGFP and a symptomatic systemic infection (Table 3).

Parallel experiments were conducted with Othello, in which the HBDBG4 (BGYMV BV1/BDMV BC1) or HBDBG6 (BDMV BV1/BGYMV BC1) were individually coinoculated into seedlings with BDMV-A or BDMVA-GFP. In these experiments, both hybrid DNA-B components mediated the efficient cell-to-cell movement of BDMVA-GFP in hypocotyl tissue (Table 3; Fig. 2I and G). The BGYMV BV1/BDMV BC1 (HBDBG4) combination did not elicit an HR (Table 3; Fig. 2J), whereas the BDMV BV1/BGYMV BC1 combination (HBDBG6) did (Table 3; Fig. 2H). These results indicated that the BDMV determinant of the HR in Othello is the BV1 ORF.
However, neither hybrid DNA-B component mediated the long-distance transport of BDMV-A (with the exception of a single symptomless plant for HBDBG4) (Table 3) or BDMVAGFP (Table 3). Thus, the HR does not appear to be necessary for BDMV resistance in Othello, and neither the BGYMV $\mathrm{BV} 1$ or $\mathrm{BC} 1$, alone in the BDMV background, was sufficient to overcome the resistance of Othello under these inoculation conditions.

\section{Mapping the BDMV avr determinant in BTS.}

To further explore the relationship between the HR and BDMV resistance in common bean, these DNA-B hybrids were used to map the BDMV avr determinant or determinants of the non-HR resistance response in BTS. In these experiments, the HBDBG1, HBDBG4, and HBDBG6 hybrid DNA-B components were individually coinoculated with either BDMVA or BDMVA-GFP into hypocotyl tissues of BTS and Topcrop. Control experiments confirmed that BTS was resistant to infection by BDMV, whereas BGYMV systemically infected BTS seedlings and induced vein yellowing in the primary leaves and golden mosaic in trifoliolate leaves (Table 4).

Consistent with previous results, all three hybrids induced a symptomatic systemic infection in Topcrop (Table 4). In BTS, BDMV-B and all three hybrids mediated the extensive cell-tocell movement of BDMVA-GFP in hypocotyl tissue, and no HR was observed for any of these combinations (Table 4).
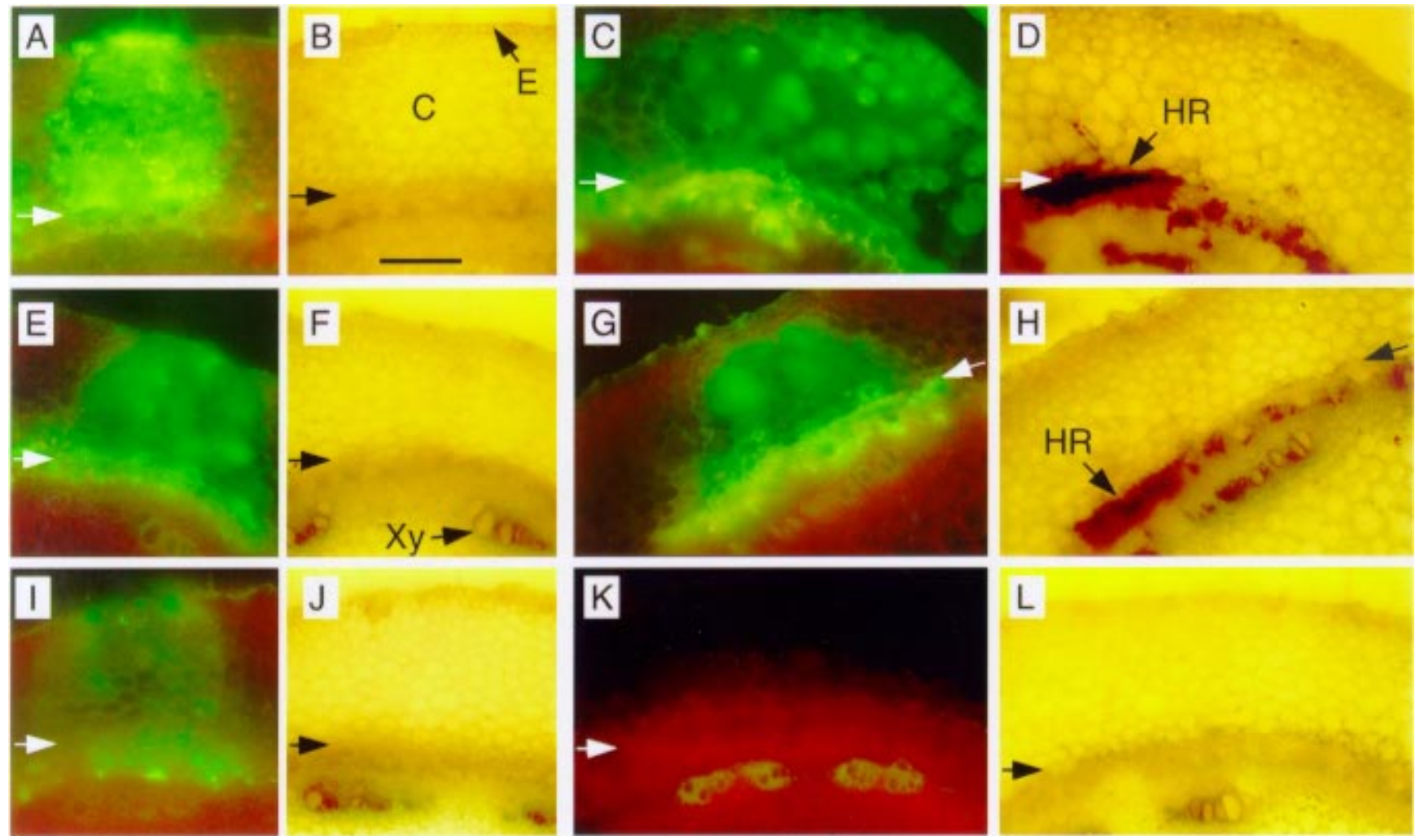

Fig. 2. Presence or absence of the hypersensitive response in common bean (cv. Othello) hypocotyls inoculated with various geminiviral constructs. Fluorescent images of transverse sections depicting green fluorescent protein (GFP) fluorescence in hypocotyl tissues inoculated with A, Bean golden yellow mosaic virus (BGYMV)-GFP; C, Bean dwarf mosaic virus (BDMV)-GFP; E, BDMVA-GFP+HBDBG1 (BGYMV BV1/BC1); G, BDMVAGFP+HBDBG6 (BDMV BV1/BGYMV BC1); I, BDMVA-GFP+HBDBG4 (BDMV BC1/BGYMV BV1), or K, gold particles alone. B, D, F, H, J, and $\mathbf{L}$, bright-field images of sections presented in A, C, E, G, I and K, respectively. All images were collected with a fluorescence microscope (Nikon Opiphot-2). Arrows without labels identify the cortex/phloem (vascular) boundary. C, E, HR, and Xy identify the location of the cortex, epidermis, hypersensitive response, and xylem, respectively. $\mathbf{B}$, Scale bar $=250 \mu \mathrm{m}$ and is common to all images presented. 
Hybrids HBDBG1 (BGYMV BV1/BC1) and HBDBG4 (BGYMV BV1/BDMV BC1), coinoculated with BDMV-A or BDMVA-GFP, mediated long-distance transport of both components in BTS and a symptomatic systemic infection (Table 4). Interestingly, the symptoms induced by HBDBG1 were BDMVlike, whereas those induced by HBDBG4 were BDMV-like, but included yellow mosaic in trifoliolate leaves. In contrast, hybrid HBDBG6 (BDMV BV1/BGYMV BC1), coinoculated with BDMV-A or BDMVA-GFP, did not mediate long-distance transport of either component in BTS (based on the failure to observe disease symptoms or detect viral DNA in trifoliolate leaves of inoculated seedlings) (Table 4). These results mapped the BDMV avr determinant in BTS to the BV1 ORF.

\section{DISCUSSION}

In this study, we conducted experiments to map viral HR or avr determinants involved in a resistance response to a bipar-

Table 3. Induction of the hypersensitive response (HR) and cell-to-cell or long-distance movement by Bean golden yellow mosaic virus (BGYMV), Bean dwarf mosaic virus (BDMV), and BDMV/BGYMV DNA-B hybrids (HBDBG4 and HBDBG6) in common bean (Phaseolus vulgaris) cvs. Othello and Topcrop

\begin{tabular}{|c|c|c|c|c|c|c|c|c|c|}
\hline \multicolumn{2}{|c|}{ Virus components ${ }^{a}$} & \multicolumn{2}{|c|}{ ORFs $^{b}$} & \multicolumn{3}{|c|}{ Othello } & \multicolumn{3}{|c|}{ Topcrop } \\
\hline $\mathbf{A}$ & B & BV1 & BC1 & $H_{R^{c}}$ & Cell $^{d}$ & $\mathbf{L D}^{\mathbf{e}}$ & HR & Cell & LD \\
\hline BGYMV-A & BGYMV-B & BG & BG & $0 / 16^{\mathrm{f}}$ & - & $7 / 21 * *$ & $0 / 10$ & - & $12 / 12 * * *$ \\
\hline BDMV-A & BDMV-B & $\mathrm{BD}$ & $\mathrm{BD}$ & $16 / 16$ & - & $0 / 10$ & $0 / 11$ & - & $12 / 12 * *$ \\
\hline BDMVA-GFP & BDMV-B & $\mathrm{BD}$ & BD & $16 / 16$ & $16 / 16$ & $0 / 10$ & $0 / 12$ & $12 / 12$ & $8 / 8 * *$ \\
\hline BDMV-A & HBDBG4 & BG & $\mathrm{BD}$ & $0 / 16$ & - & $1 / 30+$ & $0 / 12$ & - & $8 / 8 *$ \\
\hline BDMVA-GFP & HBDBG4 & BG & $\mathrm{BD}$ & $0 / 16$ & $16 / 16$ & $0 / 16$ & $0 / 12$ & $12 / 12$ & $8 / 8 *$ \\
\hline BDMV-A & HBDBG6 & $\mathrm{BD}$ & BG & $12 / 16$ & - & $0 / 8$ & $0 / 12$ & - & $8 / 8 *$ \\
\hline BDMVA-GFP & HBDBG6 & $\mathrm{BD}$ & BG & $15 / 16$ & $16 / 16$ & $0 / 8$ & $0 / 12$ & $12 / 12$ & $8 / 8 *$ \\
\hline Gold & $\ldots$ & $\ldots$ & $\ldots$ & $0 / 16$ & - & $0 / 8$ & $0 / 10$ & - & $0 / 12$ \\
\hline
\end{tabular}

a BDMVA-GFP = BDMV DNA-A (BDMV-A) tagged with the green fluorescent protein (GFP); HBDBG4 = DNA-B hybrid with the BDMV common region (CR), untranslated regions (UTRs), BC1 open reading frame (ORF), and the BGYMV BV1 ORF; HBDBG6 = DNA-B hybrid with the BDMV CR, UTRs, and BV1 ORF, and the BGYMV BC1 ORF; and Gold = gold particles used alone as a control.

${ }^{\mathrm{b}} \mathrm{BG}=\mathrm{BGYMV} \mathrm{BV} 1$ or BC1 ORF; $\mathrm{BD}=\mathrm{BDMV} \mathrm{BV} 1$ or BC1 ORF.

${ }^{\mathrm{c}} \mathrm{HR}$ was detected by examination of transverse hypocotyl sections, 4 to 5 days postinoculation (dpi), with fluorescence and light microscopy.

${ }^{\mathrm{d}}$ Cell $=$ cell-to-cell movement was assessed based on detection of GFP fluorescence, 4 to $5 \mathrm{dpi}$, in transverse hypocotyl sections with fluorescence microscopy; - indicates that cell-to-cell movement could not be observed when wild-type BDMV-A or BGYMV-A was inoculated.

${ }^{\mathrm{e}} \mathrm{LD}=$ long-distance movement (systemic infection) was determined based on symptom development (indicated by asterisks) or by polymerase chain reaction (PCR) analysis of total genomic DNA extracted from the third trifoliolate leaf, collected at 14 dpi. Relative degree of symptom development is as follows: $*=$ mild symptoms, $* *=$ moderate symptoms, $* * *=$ severe symptoms, $+=$ no symptoms, but DNA-A and DNA-B were detected by PCR with degenerate primers (Rojas et al. 1993).

${ }^{\mathrm{f}}$ Number of plants in which either HR, GFP (cell-to-cell movement), symptoms, or viral DNA (long-distance movement) were detected/total number of seedlings inoculated. Numbers represent totals for three independent experiments.

Table 4. Induction of the hypersensitive response (HR) and cell-to-cell or long-distance movement by Bean golden yellow mosaic virus (BGYMV), Bean dwarf mosaic virus (BDMV), and BDMV/BGYMV DNA-B hybrids (HBDBG4 and HBDBG6) in common bean (Phaseolus vulgaris) cvs. Black Turtle Soup T39 and Topcrop

\begin{tabular}{|c|c|c|c|c|c|c|c|c|c|}
\hline \multicolumn{2}{|c|}{ Virus components $^{\mathrm{a}}$} & \multicolumn{2}{|c|}{ ORFs $^{b}$} & \multicolumn{3}{|c|}{ Black Turtle Soup T-39 } & \multicolumn{3}{|c|}{ Topcrop } \\
\hline $\mathbf{A}$ & B & BV1 & BC1 & $\mathbf{H R}^{\mathrm{c}}$ & Cell $^{\text {d }}$ & $\mathbf{L D}^{\mathrm{e}}$ & HR & Cell & LD \\
\hline BGYMV-A & BGYMV-B & BG & BG & $0 / 12^{\mathrm{f}}$ & - & $9 / 12 * *$ & $0 / 10$ & - & $12 / 12 * * *$ \\
\hline BDMV-A & BDMV-B & BD & BD & $0 / 12$ & - & $0 / 10$ & $0 / 11$ & - & $12 / 12 * * *$ \\
\hline BDMVA-GFP & BDMV-B & $\mathrm{BD}$ & $\mathrm{BD}$ & $0 / 12$ & $12 / 12$ & $0 / 4$ & $0 / 12$ & $12 / 12$ & $8 / 8 * *$ \\
\hline BDMV-A & HBDBG1 & BG & BG & $0 / 12$ & - & $8 / 12 *+$ & $0 / 12$ & - & $8 / 8 * *$ \\
\hline BDMVA-GFP & HBDBG1 & BG & BG & $0 / 12$ & $12 / 12$ & $5 / 10 *$ & $0 / 12$ & $12 / 12$ & $8 / 8 *$ \\
\hline BDMV-A & HBDBG4 & BG & $\mathrm{BD}$ & $0 / 12$ & - & $8 / 12 *+$ & $0 / 12$ & - & $8 / 8 * *$ \\
\hline BDMVA-GFP & HBDBG4 & BG & BD & $0 / 12$ & $12 / 12$ & $6 / 12 *$ & $0 / 12$ & $12 / 12$ & $8 / 8 *$ \\
\hline BDMV-A & HBDBG6 & BD & BG & $0 / 12$ & - & $0 / 12$ & $0 / 12$ & - & $8 / 8 * *$ \\
\hline BDMVA-GFP & HBDBG6 & BD & BG & $0 / 12$ & $12 / 12$ & $0 / 12$ & $0 / 12$ & $12 / 12$ & $8 / 8 *$ \\
\hline Gold & $\ldots$ & $\ldots$ & $\ldots$ & $0 / 12$ & - & $0 / 10$ & $0 / 10$ & - & $0 / 12$ \\
\hline
\end{tabular}

${ }^{a}$ BDMVA-GFP = BDMV DNA-A (BDMV-A) tagged with the green fluorescent protein (GFP); HBDBG4 = DNA-B hybrid with the BDMV common region (CR), untranslated regions (UTRs), BC1 open reading frame (ORF), and the BGYMV BV1 ORF; HBDBG6 = DNA-B hybrid with the BDMV CR, UTRs, and BV1 ORF, and the BGYMV BC1 ORF; and Gold = gold particles used alone as a control.

${ }^{\mathrm{b}} \mathrm{BG}=\mathrm{BGYMV} \mathrm{BV} 1$ or BC1 ORF; BD = BDMV BV1 or BC1 ORF.

${ }^{\mathrm{c}} \mathrm{HR}$ was detected by examination of transverse hypocotyl sections, 4 to 5 days postinoculation (dpi), with fluorescence and light microscopy.

${ }^{\mathrm{d}}$ Cell $=$ cell-to-cell movement was assessed based on detection of GFP fluorescence, 4 to $5 \mathrm{dpi}$, in transverse hypocotyl sections with fluorescence microscopy; - indicates that cell-to-cell movement could not be observed when wild-type BDMV-A or BGYMV-A was inoculated.

${ }^{\mathrm{e}} \mathrm{LD}=$ long-distance movement (systemic infection) was determined based on symptom development (indicated by asterisks) or by polymerase chain reaction (PCR) analysis of total genomic DNA extracted from the third trifoliolate leaf, collected at 14 dpi. Relative degree of symptom development is as follows: $*=$ mild symptoms, $* *=$ moderate symptoms, $* * *=$ severe symptoms, $+=$ no symptoms, but DNA-A and DNA-B were detected by PCR with degenerate primers (Rojas et al. 1993).

${ }^{\mathrm{f}}$ Number of plants in which either HR, GFP (cell-to-cell movement), symptoms or viral DNA (long-distance movement) were detected/total number of seedlings inoculated. Numbers represent totals for three independent experiments. 
tite begomovirus. Previously, we established that (i) BDMV resistance in Othello and BTS involved a block in longdistance movement and (ii) the BDMV HR determinant in Othello mapped to BDMV-B (Wang et al. 1999). To further map the BDMV HR or avr determinants, we used BGYMV, which systemically infects Othello and BTS and does not elicit the HR in Othello. Here, we hypothesized that a specific BDMV sequence or sequences or encoded protein or proteins would be the avr determinants, whereas the homologous factor or factors in BGYMV act as virulence factors. Using a series of hybrid DNA-B components, together with markers for cellto-cell movement (GFP-tagged BDMV-A) and resistance (i.e., HR development in Othello or systemic infection in Othello and BTS), the BV1 ORF/protein was identified as a viral determinant of the HR (in Othello) and avirulence (in BTS).

Studies conducted with the HBDBG1 (BGYMV BV1/BC1 in the BDMV DNA-B background) and BDMVA-GFP in bean hypocotyl tissues established that the BDMV CR or UTR sequences allowed for replication of this hybrid DNA-B component mediated by the BDMV replication-associated protein (Rep) protein. The capacity of HBDBG1 to mediate a systemic infection in Topcrop, when coinoculated with either BDMV-A or BDMVA-GFP, further established that (i) the BGYMV MPs recognize and interact with BDMV-A to mediate its cell-to-cell and long-distance transport and (ii) that $\mathrm{CP}$ (i.e., virions) is not required for movement or development of disease symptoms. These findings are consistent with our previous results showing that BGYMV MPs can mediate cell-tocell movement of BDMVA-GFP (Sudarshana et al. 1998) and the nonspecific DNA binding properties of the BV1 and BC1 (Rojas et al. 1998). These results are also consistent with previous reports showing complementation of function among MPs of Western Hemisphere begomoviruses (Frischmuth et al. 1993; Hofer et al. 1997; Hou and Gilbertson 1996; Hou et al. 1998; Petty et al. 1995; Schaffer et al. 1995; Sung and Coutts 1995). It is worth noting that this complementation may not extend to the more distantly related Old World begomoviruses (von Arnim and Stanley 1992b).

In the BDMV-resistant Othello and BTS, the HBDBG1 hybrid did not elicit the HR (Othello) and mediated long-distance transport and systemic infection by BDMVA and BDMVAGFP in both cultivars. These results were consistent with the BDMV-B CR and UTR sequences not being determinants of HR or avr. However, compared with BGYMV, the incidence of systemic infection was low (particularly in Othello) and plants infected with HBDBG1 were symptomless (in Othello) or showed attenuated symptoms (in BTS), indicating a deficiency in the capacity of the hybrid virus to infect these BDMV-resistant cultivars. Studies with the tripartite combinations in Othello implicated the BDMV BV1 as the BDMV avr determinant, but these studies were not conclusive due to the poor level of infectivity of these tripartite viruses (even in Topcrop).

To resolve this problem, the HBDBG4 (BGYMV BV1/BDMV BC1) and HBDBG6 (BDMV BV1/BGYMV $\mathrm{BC} 1)$ hybrids were constructed. Both constructs mediated symptomatic systemic infections by BDMV-A and BDMVAGFP in Topcrop, which established that the BDMV/BGYMV MPs are functionally interchangeable in a host susceptible to both viruses. These results also suggested that the BDMV/BGYMV MPs may interact with each other as pro- posed for the Squash leaf curl virus (SLCV) BV1 and BC1 (Sanderfoot and Lazarowitz 1995). However, in a similar study with BGYMV (Guatemala isolate) and Tomato golden mosaic virus (TGMV) in Topcrop, a TGMV BV1/BGYMV BC1 hybrid was infectious, whereas a BGYMV BV1/TGMV BC1 hybrid was not (Schaffer et al. 1995). Thus, the BV1 and $\mathrm{BC} 1$ proteins of Western Hemisphere begomoviruses are not necessarily functionally interchangeable. The ability to functionally interchange the BDMV or BGYMV BV1 or BC1 proteins likely reflects the fact that both viruses are adapted to common bean and, thus, that these proteins efficiently interact with appropriate host factors. It was also interesting that none of the HBDBG hybrids, in combination with BDMV-A or BDMVA-GFP, induced golden mosaic symptoms. This indicates that BGYMV factors in addition to BV1 and BC1 (i.e., DNA-B CR, UTRs, DNA-A sequences, and gene products in various combinations) are involved in the induction of this symptom phenotype. This is consistent with findings that the TGMV or BGYMV hybrids also did not induce golden mosaic symptoms in Topcrop (Schaffer et al. 1995), and the concept that symptom induction by bipartite geminiviruses is a complex phenomenon involving multiple viral genes (Hou et al. 1998).

As with the HBDBG1 hybrid, the HBDBG4 and HBDBG6 hybrids were less infectious or caused attenuated symptoms in Othello and BTS compared with Topcrop. In BTS, HBDBG4 was infectious and induced attenuated symptoms (compared with BGYMV), whereas HBDBG6 failed to mediate a systemic infection by BDMV-A or BDMVA-GFP; these results mapped the BDMV avr determinant to the BV1 ORF. The differences in the responses of these common bean cultivars to infection mediated by the HBDBG hybrids may be due to the higher levels of resistance to BGYMV infection in common bean genotypes of Mesoamerican origin, such as Othello and BTS, compared with genotypes of Andean origin, such as Topcrop (Garrido-Ramirez et al. in press; Gilbertson et al. 1991b; Morales and Niessen 1988). For example, accumulation of BGYMV (Guatemalan isolate) in equivalent leaves of sap-inoculated plants was considerably reduced in Mesoamerican cv. Pinto 114 compared with Topcrop (Gilbertson et al. 1991b). The mechanism of this resistance is not known, but could be due to interference with viral replication or movement. In terms of the HBDBG hybrids, less efficient replication of BDMV-A and BDMVA-GFP in Othello and BTS compared with Topcrop would have a negative impact on infectivity. Another possibility is that the capacity of the hybrid viruses to mediate long-distance transport of BDMV-A and BDMVA-GFP might be influenced by the growth habit of the cultivar. Thus, the HBDBG hybrids may not efficiently mediate long-distance transport of BDMV-A and BDMVAGFP in the rapid-growing indeterminant Othello; whereas, in Topcrop, a determinant bush type, these hybrids may be more efficient in mediating long-distance transport and systemic infection. In terms of the HBDBG4 and HBDBG6 hybrids, inefficiencies in the interactions between the BDMV and BGYMV MPs also could negatively impact long-distance transport in Othello and BTS. Regardless of the mechanism, these results suggest that BGYMV has additional virulence factors, other than $\mathrm{BV1}$ and $\mathrm{BC} 1$, that allow it to infect Othello and BTS, and that equivalent BDMV factors may interact less efficiently with host factors in these cultivars. 
The finding that the hybrid having the BDMV BV1 (HBDBG6) elicited the HR, whereas that with the BGYMV BV1 (HBDBG4) did not, mapped the determinant of the HR to the BV1 ORF. Results with the tripartite combinations, in which viruses having the frameshifted BV1 ORF failed to elicit the HR, are consistent with the hypothesis that the BV1 protein, rather than the ORF or mRNA, is the HR elicitor. The fact that the HBDBG4 hybrid (BGYMV BV1/BDMV BC1), coinoculated with BDMVA or BDMVA-GFP, failed to mediate a systemic infection in Othello, despite not eliciting an HR in inoculated hypocotyl tissue, suggests that the HR is not necessary for BDMV resistance. Indeed, there are other examples where the HR has been uncoupled from resistance, such as the CMV-cowpea interaction, where an inhibition (resistance) response was shown to be independent of the HR (Kim and Palukaitis 1997). The fact that the HR does not appear to be necessary for BDMV resistance in Othello also raises the question of whether the genes involved in BDMV resistance in Othello and BTS are the same or different. The answer to this question will have to be determined by genetic studies on the host side.

Finally, insight into the manner by which the BDMV BV1 acts as an HR/avr determinant can be gained from an analysis of the role played by this protein in the viral life cycle. The BV1 protein is a nuclear shuttle, and facilitates the export of viral ss- and dsDNA from the nucleoplasm to the cytoplasm, where the $\mathrm{BC} 1$ protein mediates the cell-to-cell movement of the DNA through plasmodesmata (Noueiry et al. 1994; Rojas et al. 1998). The role of the BDMV BV1 protein as an HR/avr determinant may involve active recognition at the nuclear pore complex by an endogenous receptor. This may occur within the nucleoplasm or the cytoplasm. Here, it is interesting to note that certain bacterial avr factors are also targeted to the nucleus, where recognition and initiation of the HR and host defense response may occur (Gabriel 1997). An alternative explanation is that an inefficient interaction of the BDMV BV1 with host factors in Othello and BTS allows for activation of host defense responses and a restriction of longdistance movement. In contrast, the BGYMV BV1 protein is either not recognized in Othello and BTS, is recognized but suppresses the host defense response, or simply interacts more efficiently with host factors such that it allows for BGYMV to escape the host defense response. Irrespective of the mechanism and site of action, the BDMV BV1 represents an additional class of viral HR/avr determinants (Culver 1996). Further insight into the mechanism or mechanisms of BDMV resistance in Othello and BTS will require genetic analyses or the cloning and characterization of the host genes involved in the resistance.

\section{MATERIALS AND METHODS}

\section{BDMV and BGYMV infectious clones and constructs.}

Infectious 1.5-mer clones of BDMV-A (pBDA1.5), BDMVB (pBDB1.5), BGYMV (Mexican strain, BGMV-MX; hereafter referred to as BGYMV) DNA-A (BGMV-A; pBGMXA1.5), BGYMV DNA-B (BGMV-B; pBGMXB1.5), and BDMVA-GFP (pBDAGFP) have been previously described (Garrido-Ramirez and Gilbertson 1996; Hou et al. 1998; Sudarshana et al. 1998). BGMVA-GFP (pBGAGFP) was constructed using the approach described in Sudarshana et al. (1998). BDMV BV1 and BC1 fs mutants have also been described (Noueiry et al. 1994). An infectious 1.5-mer hybrid DNA-B having the BDMV CR and UTR sequences and BGYMV BV1 and BC1 ORFs was engineered. For this purpose, oligonucleotide primer pairs (OBDBv2096E and OBDBc563N, and OBDBv2237N and OBDBc496H; primer sequences available upon request) and Ultma (Perkin-Elmer, Foster City, CA, U.S.A.) were used in polymerase chain reaction (PCR) to amplify two fragments, each containing the BDMV CR and UTRs from pBDB1.5, and to introduce appropriate restriction sites into these fragments. PCR parameters used for all steps of the plasmid constructions were as follows: one cycle of $94^{\circ} \mathrm{C}, 4 \mathrm{~min}$; hot start at $80^{\circ} \mathrm{C}, 2 \mathrm{~min}$; $45^{\circ} \mathrm{C}, 1 \mathrm{~min}$; and $72^{\circ} \mathrm{C}, 2 \mathrm{~min}$; followed by nine cycles of $94^{\circ} \mathrm{C}, 1 \mathrm{~min} ; 55^{\circ} \mathrm{C}, 1 \mathrm{~min} ; 72^{\circ} \mathrm{C}, 3 \mathrm{~min}$; and a final extension cycle of $72^{\circ} \mathrm{C}, 10 \mathrm{~min}$. The PCR-amplified BDMV-B fragments were cloned with the Zero blunt cloning system (Invitrogen, Carlsbad, CA, U.S.A.) to generate the recombinant plasmids $\mathrm{pBD} 1$ and $\mathrm{pBD} 2$, respectively. The BDMV DNA-B CR and UTRs were excised from pBD1 as an NheI/XhoI fragment, and subcloned into $\mathrm{pBD} 2$ to generate pBD3, which contained two copies of the CR and UTRs.

Oligonucleotide primers OBGBv505N and OBGBc2180N were used to amplify a 1,600-bp BGYMV DNA-B fragment

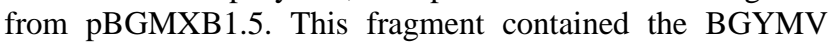
$\mathrm{BV} 1$ and $\mathrm{BC} 1 \mathrm{ORFs}$ with introduced NheI restriction sites at the beginning of each ORF. This PCR-amplified fragment was cloned using the Zero blunt system to generate pBG1, and the nucleotide sequence from each of the introduced NheI sites up to the ClaI site in BV1 and the $B g l \mathrm{II}$ site in $\mathrm{BC} 1$ verified. The $1.1-\mathrm{kb} C l a \mathrm{I} / B g l \mathrm{II}$ fragment of $\mathrm{pBG1}$ was then replaced with the equivalent fragment from $\mathrm{pBGMXB1.5}$ (wild-type BGYMV DNA-B) to generate pBG1A. The NheI fragment, containing the BGYMV BV1 and BC1 ORFs, was excised from pBG1A and cloned into NheI-digested pBD3 to generate pHBDBG1, after which the sequences around the NheI sites were verified. This 1.5-mer construct contained two BDMV CRs and UTRs and the BGYMV BV1 and BC1 ORFs (Fig. 1).

\section{BV1 and BC1 fs mutants in pHBDBG1.}

Oligonucleotide primers OBDBGBV1mut and OBV1c1044 and PCR were used to amplify a 500-bp BGYMV BV1 fragment from pBGMXB2, and to introduce NheI and HindIII restriction sites into the $5^{\prime}$ and $3^{\prime}$ ends, respectively, and an fs mutation into the $5^{\prime}$ end of BV1. The PCR-amplified BV1 fragment was cloned with the Zero blunt system to generate $\mathrm{pBGBV}_{\mathrm{fs}}$. A 1,400-bp XhoI/ClaI fragment from pHBDBG1 was subcloned into pKS+ (Stratagene, La Jolla, CA, U.S.A.) to generate pBGBV1. This plasmid was digested with NheI and ClaI, and the 200-bp NheI/ClaI BV1 fragment was exchanged with the corresponding fragment from $\mathrm{pBGBV} 1_{\mathrm{fs}}$ to produce $\mathrm{pBGBV} 1_{\mathrm{fs}} 2$. The 1,400-bp XhoI/ClaI fragment from $\mathrm{pBGBV} 1_{\mathrm{fs}} 2$ was excised and exchanged with the corresponding fragment in $\mathrm{pHBDBG} 1$ to generate $\mathrm{pHBDBGBV} 1_{\mathrm{fs}}$. This 1.5-mer construct contained two BDMV-B CRs and UTRs, and the BGYMV BV1 $1_{\mathrm{fs}}$ and BC1 ORFs (Fig. 1).

To generate a $\mathrm{BC}_{\mathrm{fs}}$ mutant, oligonucleotide primers OBDBGBC1mut and OBC1v1426 and PCR were used to amplify an 800-bp BGYMV BC1 fragment from pBGMXB2 and to introduce NheI and BamHI restriction sites into the 5' and $3^{\prime}$ ends, respectively, and an fs mutation into the $5^{\prime}$ end of 
BC1. The PCR-amplified BC1 fragment was cloned with the Zero blunt system to generate $\mathrm{pBGBC} 1_{\mathrm{fs}}$. A 1,200-bp HindIII fragment from $\mathrm{pHBDBG} 1$ was subcloned into $\mathrm{pKS}+$ to generate pBGBC1. This plasmid was digested with SacI and NheI (Fig. 1), and the 300-bp SacI/NheI BC1 fragment was exchanged with the corresponding fragment from $\mathrm{pBGBC} 1_{\mathrm{fs}}$ to produce $\mathrm{pBGBC}_{\mathrm{fs}} 2$. The 1,200-bp HindIII fragment from $\mathrm{pBGBC}_{\mathrm{fs}} 2$ was excised and exchanged with the corresponding fragment in $\mathrm{pHBDBG} 1$ to generate $\mathrm{pHBDBGBC} 1_{\mathrm{fs}}$. This 1.5-mer construct contained two BDMV-B CRs and UTRs, and the BGYMV BV1 and $\mathrm{BC} 1_{\mathrm{fs}}$ ORFs (Fig. 1).

\section{Generation of hybrids containing BGYMV BV1/ BDMV BC1 and BDMV BV1/BGYMV BC1.}

The recombinant plasmid pHBDBG1 was digested with EcoRI to release a 3.5-kb fragment that contained the BDMV $\mathrm{CR}$ and UTR sequences and the BGYMV BV1 and BC1 ORFs. This 3.5-kb fragment was subcloned into pALTER (Promega Corp., Madison, WI, U.S.A.) to generate pHBDBG2, in order to facilitate site-directed mutagenesis. Primer OBDBc1309X was used with the Altered Sites II Mutagenesis System (Promega Corp.) to introduce an XbaI site into the $3^{\prime}$ end of the BGYMV BV1 ORF in pHBDBG2 to generate pHBDBG3. Primers OBDBv1297X and OBDBc2248S and PCR were used to amplify a 900-bp fragment from pBDB1.5 that contained the $3^{\prime}$ end of the BV1 ORF and the entire BC1 ORF; these primers also introduced an $\mathrm{XbaI}$ site into the $3^{\prime}$ end of the BDMV BV1 ORF and a SpeI site into the $5^{\prime}$ end of the BC1 ORF. This PCR-amplified fragment was cloned with the Zero blunt system to generate $\mathrm{pBDB} X S$, and the sequence verified. The XbaI/SpeI BDMV BV1/BC1 fragment from pBDBXS was excised and cloned into XbaI/NheI-digested and dephosphorylated pHBDBG3 to generate pHBDBG4, which contained the BGYMV BV1 ORF and the remainder of the BDMV-B sequence (Fig. 1).

Primers OBDBGH2 and OBDBGH3 were used with the Altered Sites II Mutagenesis System to introduce BspEI and $X b a \mathrm{I}$ sites into the $5^{\prime}$ and $3^{\prime}$ ends of the BGYMV BV1 ORF, respectively, in $\mathrm{pHBDBG} 2$ to generate $\mathrm{pHBDBG5}$. Primers OBDBv554B and OBDBc1309X and PCR were used to amplify a 700-bp fragment from pBDB1.5 that contained the BDMV BV1 ORF with BspEI and XbaI sites in the $5^{\prime}$ and $3^{\prime}$ ends, respectively. This PCR-amplified fragment was cloned with the Zero blunt system to generate $\mathrm{pBDB} B X$, and the sequence of the cloned product verified. The $B s p \mathrm{EI} / X b a \mathrm{I}$ BDMV BV1 fragment from $\mathrm{pBDB} B X$ was excised and cloned into $B s p \mathrm{EI} / \mathrm{Xba \textrm {I }}$-digested and dephosphorylated pHBDBG5 to generate pHBDBG6, which contained the BGYMV BC1 ORF and the remainder of the BDMV-B sequence (Fig. 1).

\section{Inoculation of Phaseolus vulgaris seedlings by particle bombardment.}

Seeds of Phaseolus vulgaris L. (common bean cvs. Topcrop, Othello, and BTS) were germinated at room temperature on moist filter paper in plastic petri dishes. Bean seedlings were inoculated by particle bombardment as previously described (Paplomatas et al. 1994; Sudarshana et al. 1998). Seedlings were coinoculated with each of the DNA-B constructs and either BDMV-A or BDMVA-GFP and grown as previously described (Sudarshana et al. 1998).

\section{Detection of GFP expression and the HR.}

Expression of GFP, at the whole plant level, was detected with a handheld long-wavelength UV lamp (UVP, Upland, CA, U.S.A.). To detect the HR, seedlings were carefully removed from the soil approximately 5 days postinoculation (dpi), and freehand transverse-sections of hypocotyl tissue were prepared and examined with light and fluorescent microscopy, as previously described (Sudarshana et al. 1998; Wang et al. 1999). To assess systemic infection, seedlings were grown for 14 to 21 days, and then observed for disease symptom development and the presence of GFP in newly emerged leaves. In some cases, symptomless plants were tested for systemic infection by PCR with degenerate primers.

\section{DNA extraction and PCR detection of geminiviral DNA.}

DNA extraction and PCR parameters used to amplify geminivirus DNA fragments have been previously described (Gilbertson et al. 1991c; Rojas et al. 1993). DNA extracts were prepared from the first trifoliolate leaves (approximately 15 dpi). Viral DNA fragments were amplified using the degenerate PCR primer pairs PAC1v1978/PAV1c970, PGFPv67/ PGFPc94, or PBC1v2040/PBV1c970 (Garrido-Ramirez and Gilbertson 1998; Rojas et al. 1993; Sudarshana et al. 1998). Aliquots of PCR reactions were examined by electrophoresis in $0.7 \%$ agarose gels in 0.5 Tris-borate-EDTA buffer.

\section{DNA sequence analyses.}

DNA sequencing was conducted by the University of California-Davis Sequencing Facility or Davis Sequencing (Davis) with a Perkin-Elmer/ABI 377 automated DNA sequencer using either dRhodamine terminator or Big Dye terminator chemistry (Perkin-Elmer/ABI, Foster City, CA, U.S.A.). DNA sequence analyses were performed using the GCG sequence analysis software package (version 9.1; Genetics Computer Group, Madison, WI, U.S.A.).

\section{ACKNOWLEDGMENTS}

This research was supported by the United States Department of Agriculture National Research Initiative Competitive Grants Program (9901578 to R. L. G. and W. J. L.). E. R. G.-R. was the recipient of a doctoral fellowship from CONACYT (Mexico). We also thank the reviewers of the manuscript for their insightful comments.

\section{LITERATURE CITED}

Agrios, G. N. 1997. Plant Pathology. 4th ed. Academic Press, New York. Bendahamane, A., Kohm, B. A., Dedi, C., and Baulcombe, D. C. 1995. The coat protein of potato virus $\mathrm{X}$ is a strain-specific elicitor of $R \times 1$ mediated resistance in potato. Plant J. 8:933-941.

Berzal-Herranz, A., De La Cruz, A., Tenllado, F., Diaz-Ruiz, J. R., Lopez, L., Sanz, A. I., Vaquero, C., Serra, M. T., and Garcia-Luque, I. 1994. The Capsicum L3 gene-mediated resistance against tobamoviruses is elicited by the coat protein. Virology 209:498-505.

Brough, C. L., Hayes, R. J., Morgan, A. J., Coutts, R. H., and Buck, K. W. 1988. Effects of mutagenesis in vitro on the ability of cloned tomato golden mosaic virus DNA to infect Nicotiana benthamiana plants. J. Gen. Virol. 69:503-514.

Chu, M., Park, J.-W., and Scholthof, H. B. 1999. Separate regions on the tomato bushy stunt virus p22 protein mediate cell-to-cell movement versus elicitation of effective resistance responses. Mol. PlantMicrobe Interact. 12:285-292.

Culver, J. 1996. Viral avirulence genes. Pages 196-219 in: Plant Microbe Interactions. G. Stacey and N. T. Keen, eds. Chapman and Hall, New York. 
Culver, J. M., and Dawson, W. O. 1989. Point mutations in the coat protein gene of tobacco mosaic virus induce hypersensitivity in Nicotiana sylvestris. Mol. Plant-Microbe Interact. 2:209-213.

Dangl, J. L., Dietrich, R. A., and Richberg, M. H. 1996. Death don't have no mercy: Cell death programs in plant microbe interactions. Plant Cell 8:1793-1807.

Etessami, P., Callis, R., Ellwood, S., and Stanley, J. 1988. Delimitation of essential genes of cassava latent virus DNA 2. Nucleic Acid Res. 16:4811-4829.

Flor, H. H. 1971. Current status of the gene-for-gene concept. Annu. Rev. Phytopathol. 9:275-296.

Frischmuth, T., Roberts, S., von Arnim, A., and Stanley, J. 1993. Specificity of bipartite geminivirus movement proteins. Virology 196:666-673.

Gabriel, D. W. 1997. Targeting of protein signals from Xanthomonas to the plant nucleus. Trends Plant Sci. 2:204-206.

Gabriel, D. W., and Rolfe, B. K. 1990. Working models of specific recognition in plant-microbe interactions. Annu. Rev. Phytopathol. 28:365-391.

Garrido-Ramirez, E. R., and Gilbertson, R. L. 1996. Molecular characterization of bean golden mosaic geminivirus (BGMV) from Chiapas, Mexico. (Abstr.) Phytopathology 86(suppl.):S17.

Garrido-Ramirez, E. R., and Gilbertson, R. L. 1998. First report of tomato mottle geminivirus infecting tomatoes in Yucatan, Mexico. Plant Dis. 82:592.

Garrido-Ramirez, E. R., Sudarshana, M. R., and Gilbertson, R. L. Bean golden yellow mosaic virus from Chiapas, Mexico: Characterization, pseudorecombination with other bean-infecting geminiviruses and germ plasm screening. Phytopathology. In press.

Gilbertson, R. L., Faria, J. C., Hanson, S. F., Morales, F. J., Ahlquist, P., and Maxwell, D. P. 1991a. Cloning of the complete DNA genomes of four bean-infecting geminiviruses and determining their infectivity by electric discharge particle acceleration. Phytopathology 81:980-985.

Gilbertson, R. L., Hidayat, S. H., Martinez, R. T., Leong, S. A., Faria, J. C., Morales, F., and Maxwell, D. P. 1991b. Differentiation of bean infecting geminiviruses by nucleic acid hybridization probes and aspects of bean golden mosaic in Brazil. Plant Dis. 75:336-342.

Gilbertson, R. L., Hidayat, S. H., Paplomatas, E. J., Rojas, M. R., Hou, Y. M., and Maxwell, D. P. 1993. Pseudorecombination between infectious cloned DNA components of tomato mottle and bean dwarf mosaic geminiviruses. J. Gen. Virol. 74:23-31.

Gilbertson, R. L., Rojas, M. R., Russell, D. R., and Maxwell, D. P. 1991c. Use of asymmetric polymerase chain reaction and DNA sequencing to determine genetic variability of bean golden mosaic geminivirus in the Dominican Republic. J. Gen. Virol. 72:2843-2848.

Gilchrist, D. G. 1998. Programmed cell death in plant disease: The purpose and promise of cellular suicide. Annu. Rev. Phytopathol. 36:393414.

Goodman, R. N., and Novacky, A. J. 1994. The Hypersensitive Reaction in Plants to Pathogens. American Phytopathological Society, St. Paul., MN, U.S.A.

Hidayat, S. H. 1991. The construction and application of DNA probes for the detection of bean dwarf mosaic geminivirus. M.S. thesis. University of Wisconsin, Madison, U.S.A.

Hidayat, S. H., Gilbertson, R. L., Hanson, S. F., Morales, F. J., Ahlquist, P., Russell, D. R., and Maxwell, D. P. 1993. Complete nucleotide sequence of the infectious cloned DNAs of bean dwarf mosaic geminivirus. Phytopathology 83:181-187.

Hofer, P., Engel, M., Jeske, H., and Frischmuth, T. 1997. Host range limitation of a pseudorecombinant virus produced by two distinct bipartite geminiviruses. Mol. Plant-Microbe Interact. 10:1019-1022.

Hou, Y. M., and Gilbertson, R. L. 1996. Increased pathogenicity in a pseudorecombinant bipartite geminivirus correlates with intermolecular recombination. J. Virol. 70:5430-5436.

Hou, Y. M., Paplomatas, E. J., and Gilbertson, R. L. 1998. Host adaptation and replication properties of two bipartite geminiviruses and their pseudorecombinants. Mol. Plant-Microbe Interact. 11:208-217.

Hou, Y. M., Sanders, R., Ursin, V. M., and Gilbertson, R. L. 2000. Transgenic plants expressing geminivirus movement proteins: Abnormal phenotypes and delayed infection by Tomato mottle virus in transgenic tomatoes expresing Bean dwarf mosaic virus $\mathrm{BV} 1$ or $\mathrm{BC} 1$ proteins. Mol. Plant-Microbe Interact. 13:297-308.

Ingham, A. J., and Lazarowitz, S. 1993. A single missense mutation in the BR1 movement protein alters the host range of the squash leaf curl geminivirus. Virology 196:694-702.
Ingham, A. J., Pascal, E., and Lazarowitz, S. 1995. Both bipartite geminivirus movement proteins define viral host range, but only BL1 determines viral pathogenicity. Virology 207:191-204

Jeffrey, J. L., Pooma, W., and Petty, I. T. D. 1996. Genetic requirements for local and systemic movement of tomato golden mosaic virus in infected plants. Virology 223:208-218

Kavanaugh, T., Goulden, M., Santa Cruz, S., Chapman, S., Barker, I., and Baulcombe, D. 1992. Molecular analysis of a resistance-breaking strain of potato virus X. Virology 189:609-617.

Keen, N. 1990. Gene-for-gene complementarity in plant-pathogen interactions. Annu. Rev. Genet. 24:447-463.

Kim, C.-H., and Palukaitis, P. 1997. The plant defense response to cucumber mosaic virus in cowpea is elicited by the viral polymerase gene and affects virus accumulation in single cells. EMBO J. 16:4060-4068.

Kiraly, L., Cole, A. B., Bourque, J. E., and Schoelz, J. E. 1999. Systemic cell death is elicited by the interaction of a single gene in Nicotiana clevelandii and gene VI of cauliflower mosaic virus. Mol. Plant Microbe Interact. 12:919-925.

Knorr, D. A., and Dawson, W. O. 1988. A point mutation in the tobacco mosaic virus capsid protein gene induces hypersensitivity in Nicotiana sylvestris. Proc. Natl. Acad. Sci. USA 85:170-174.

Lamb, C. J., Lawton, M. A., Dron, M., and Dixon, R. A. 1989. Signals and transduction mechanisms for activation of plant defenses against microbial attack. Cell 56:215-224.

Malcuit, I., Marano, M. R., Kavanagh, T., De Jong, W., Forsyth, A., and Baulcombe, D. C. 1999. The 25-kDa movement protein of PVX elicits $\mathrm{Nb}$-mediated hypersensitive cell death in potato. Mol. PlantMicrobe Interact. 12:536-543.

Meshi, T., Motoyoshi, F., Maeda, T., Yoshiwoka, S., Watanabe, H., and Okada, Y. 1989. Mutations in the tobacco mosaic virus $30-\mathrm{kD}$ protein gene overcome Tm-2 resistance in tomato. Plant Cell 1:515-522.

Morales, F. J., and Niessen, A. I. 1988. Comparative response of selected Phaseolus vulgaris germ plasm inoculated artificially and naturally with bean golden mosaic virus. Plant Dis. 72:1020-1023.

Morales, F. J., Niessen, A., Ramirez, B., and Castaño, M. 1990. Isolation and partial characterization of a geminivirus causing bean dwarf mosaic. Phytopathology 80:96-101.

Morel, J. B., and Dangl, J. L. 1997. The hypersensitive response and the induction of cell death in plants. Cell Death Differ. 4:1318-1328.

Noueiry, A. O. 1995. Molecular and biochemical analysis of mechanisms involved in the movement of a bipartite geminivirus in plants. Ph.D. diss. University of California, Davis, U.S.A.

Noueiry, A. O., Lucas, W. J., and Gilbertson, R. L. 1994. Two proteins of a plant DNA virus coordinate nuclear and plasmodesmal transport. Cell 76:925-932.

Padgett, H. S., and Beachy, R. N. 1993. Analysis of tobacco mosaic virus strain capable of overcoming $\mathrm{N}$ gene-mediated resistance. Plant Cell 5:577-586

Paplomatas, E. J., Patel, V. P., Hou, Y. M., Noueiry, A. O., and Gilbertson, R. L. 1994. Molecular characterization of a new sap-transmissible bipartite genome geminivirus infecting tomatoes in Mexico. Phytopathology 84:1215-1224.

Pascal, E., Goodlove, P. E., Wu, L. C., and Lazarowitz, S. G. 1993. Transgenic tobacco plants expressing the geminivirus BL1 protein exhibit symptoms of viral disease. Plant Cell 5:795-807.

Pascal, E., Sanderfoot, A. A., Ward, B. M., Medville, R., Turgeon, R., and Lazarowitz, S. G. 1994. The geminivirus BR1 movement protein binds single-stranded DNA and localizes to the cell nucleus. Plant Cell 6:995-1006

Petty, I. T. D., Miller, C. G., Meade-Hash, T. J., and Schaffer, R. L. 1995. Complementable and noncomplementable host adaptation defects in bipartite geminiviruses. Virology 212:263-267.

Richael, C., and Gilchrist, D. 1999. The hypersensitive response: A case of hold or fold? Physiol. Mol. Plant Pathol. 55:5-12.

Rojas, M. R., Gilbertson, R. L., Russell, D. R., and Maxwell, D. P. 1993. Use of degenerate primers in the polymerase chain reaction to detect whitefly-transmitted geminiviruses. Plant Dis. 77:340-347.

Rojas, M. R., Noueiry, A. O., Lucas, W. J., and Gilbertson, R. L. 1998. Bean dwarf mosaic geminivirus movement proteins recognize DNA in a form- and size-specific manner. Cell 95:105-113.

Saito, T., Meshi, T., Takamatsu, N., and Okada, Y. 1987. Coat protein gene sequence of tobacco mosaic virus encodes a host response determinant. Proc. Natl. Acad. Sci. USA 84:6074-6077. 
Sanderfoot, A. A., and Lazarowitz, S. G. 1995. Cooperation in viral movement: The geminivirus BL1 movement protein interacts with BR1 and redirects it from the nucleus to the cell periphery. Plant Cell 7:1185-1194.

Schaffer, R. L., Miller, C. G., and Petty, I. 1995. Virus and host adaptation in the BL1 and BR1 genes of bipartite geminiviruses. Virology 214:330-338

Schoelz, J., Shepherd, R. J., and Daubert, S. 1986. Region VI of cauliflower mosaic virus encodes a host range determinant. Mol. Cell. Biol. 6:2632-2637.

Scholthof, H. B., Scholthof, K.-B. G., and Jackson, A. O. 1995. Identification of tomato bushy stunt virus host-specific symptom determinants by expression of individual genes from a potato virus $\mathrm{X}$ vector. Plant Cell 7:1157-1172.

Staskawicz, B. J., Ausubel, F. M., Baker, B. J., Ellis, J. G., and Jones, J. D. G. 1995. Molecular genetics of plant disease resistance. Science 268:661-667.

Sudarshana, M. R., Wang, H. L., Lucas, W. J., and Gilbertson, R. L. 1998. Dynamics of bean dwarf mosaic geminivirus cell-to-cell and long distance movement in Phaseolus vulgaris revealed, using the green fluorescent protein. Mol. Plant-Microbe Interact. 11:277-291.
Sung, Y. K., and Coutts, R. H. A. 1995. Pseudorecombination and complementation between potato yellow mosaic geminivirus and tomato golden mosaic geminivirus. J. Gen. Virol. 76:2809-2815.

Timmermans, M. C. P., Das, O. P., and Messing, J. 1994. Geminiviruses and their uses as extrachromosomal replicons. Annu. Rev. Plant Physiol. Plant Mol. Biol. 45:79-112.

von Arnim, A., and Stanley, J. 1992a. Determinants of tomato golden mosaic virus symptom development located on DNA B. Virology 186:286-293.

von Arnim, A., and Stanley, J. 1992b. Inhibition of African cassava mosaic virus infection by a movement protein from the related tomato golden mosaic virus. Virology 187:555-564.

Wang, H. L., Sudarshana, M. R., Gilbertson, R. L., and Lucas, W. J. 1999. Analysis of cell-to-cell and long-distance movement of a bean dwarf mosaic geminivirus-green fluorescent protein reporter in host and nonhost species: identification of sites of resistance. Mol. PlantMicrobe Interact. 12:345-355.

Weber, H., Schultze, S., and Pfitzner, A. J. P. 1993. Two amino acid substitutions in the tomato mosaic virus 30-kilodalton movement protein confer the ability to overcome the Tm- $2^{2}$ resistance gene in tomato. J. Virol. 67:6432-6438. 